\title{
Título do sítio electrónico: HOWIEs home page
}

URL: http://home.earthlink.net/ hsbecker/

\section{João Aldeia}

\section{(2) OpenEdition \\ Journals}

Edição electrónica

URL: http://journals.openedition.org/rccs/528

DOI: $10.4000 /$ rccs. 528

ISSN: 2182-7435

\section{Editora}

Centro de Estudos Sociais da Universidade de Coimbra

\section{Edição impressa}

Data de publição: 1 junho 2009

Paginação: 183

ISSN: 0254-1106

Refêrencia eletrónica

João Aldeia, «Título do sítio electrónico: HOWIEs home page », Revista Crítica de Ciências Sociais

[Online], 85 | 2009, posto online no dia 01 outubro 2012, consultado o 22 setembro 2020. URL : http:// journals.openedition.org/rccs/528; DOI : https://doi.org/10.4000/rccs.528 


\section{Espaço Virtual}

\section{Título do sítio electrónico: HOWIEs home page URL: http://home.earthlink.net/ hsbecker/}

Na página electrónica pessoal de Howard Saul Becker (1928-) é possível encontrar informação de interesse académico mas também de carácter pessoal sobre este sociólogo da Escola de Chicago - fotografias pessoais do autor, links que remetem para outras páginas electrónicas por ele apreciadas, curiosidades várias ou faixas de música executadas pelo próprio. A página tem uma apresentação visualmente apelativa e simples, sendo de fácil navegação. Entre a informação nela presente, destacam-se vários artigos da autoria de Becker e entrevistas a ele realizadas, disponíveis para download, que abrangem uma considerável variedade de temáticas. A grande maioria destes textos é de difícil obtenção por outra via, e alguns ainda não foram sequer publicados. A nova edição da obra Art Words, ${ }^{1}$ publicada por ocasião dos 25 anos passados desde a primeira edição, contém um novo prefácio - "Making it up as you go along: How I wrote Art Worlds" - e um novo epílogo - "A Dialogue on the Ideas of 'World' and 'Field'" - que se encontravam disponíveis nesta página até à sua publicação. Está também disponível uma lista bibliográfica das obras do autor, com pequenas sinopses de cada um dos seus livros (não sendo possível adquiri-los directamente, remetem o utilizador para o site da Amazon.com, onde o poderá fazer). Encontram-se ainda na página notícias e novidades relativas a conferências em que Becker estará presente e a novas publicações de livros seus. Por último, o contacto electrónico de Becker está também disponível, mostrando-se este disposto a responder a quaisquer questões académicas acerca do seu trabalho, desde que estas não sejam urgentes. Apesar de se tratar de um página pessoal e conter algumas informações que poderão não ter relevância para quem se interesse somente pelo trabalho do autor, a disponibilização dos seus artigos revela-se academicamente muito útil.

\section{Título do sítio electrónico: Fédération Européenne des Associations Nacionales Travaillant avec les Sans-Abri e European Observatory on Homelessness
URLs: http://www.feantsa.org/code/en/hp.asp e http://eohw.horus.be/ code/EN/hp.asp

Optou-se por apresentar conjuntamente as duas páginas pela sua estreita articulação temática e institucional. Criada em 1989, a FEANTSA - Fédération Européenne des
Associations Nacionales Travaillant avec les Sans-Abri - é uma organização não-governamental (ONG) dedicada a eliminar a pobreza e exclusão social de indivíduos

${ }^{1}$ Becker, Howard S. (2008), Art Worlds. Berkeley e Los Angeles: University of California Press. [1 $1^{\mathrm{a}}$ edição 1982] 
sem-abrigo ou em risco de conhecer esta situação, que congrega mais de 100 ONGs locais e nacionais de vários Estados-membros da União Europeia, sendo financiada pela Comissão Europeia e tendo estatuto de consultora no Conselho Europeu e nas Nações Unidas. O European Observatory on Homelessness (EOH), da FEANTSA, foi criado há quase duas décadas e produz uma vasta investigação acerca desta temática sob a forma de dados estatísticos, relatórios, livros e artigos. É ainda responsável pela realização de uma conferência temática anual em torno do fenómeno dos sem-abrigo e, desde 2007, publica anualmente o European Journal of Homelessness - EJH. É possível aceder à página electrónica do EOH através da página da FEANTSA, pelo menu do lado esquerdo (feantsa research), ou directamente pelo endereço acima indicado.

A apresentação gráfica de ambas as páginas é inicialmente confusa, em parte pela grande quantidade de informação disponibilizada e pelo recurso a um tamanho de caracteres e cores que não facilitam a navegação. Contudo, após alguns minutos de habituação, é possível encontrar dados muito relevantes sobre o tema. Destes destacam-se vários relatórios do Parlamento Europeu acerca do fenómeno dos sem- abrigo e informação sobre iniciativas em que outros órgãos europeus estiveram envolvidos; ferramentas conceptuais desenvolvidas pela FEANTSA que se revelam úteis para a investigação sobre o fenómeno (de realçar a tipologia ETHOS - European Typology of Homelessness and Housing Exclusion); informação sobre diversas estratégias e iniciativas locais, nacionais e transnacionais dirigidas aos sem-abrigo; informação relativa a conferências e seminários europeus sobre a temática, promovidos pela própria FEANTSA ou por outra organização; a newsletter da FEANTSA e a revista electrónica temática Homelessness in Europe, publicada três vezes ao ano. Os resultados da investigação desenvolvida pelo $\mathrm{EOH}$, os programas e comunicados apresentados nas diversas conferências e os relatórios de organizações europeias encontram-se maioritariamente disponíveis para download, exceptuando os que tenham sido publicados sob a forma de livro, que podem ser adquiridos através da página. Finalmente, é possível aceder a uma base de dados de publicações europeias relevantes sobre o fenómeno dos sem-abrigo, apesar das obras não poderem ser consultadas neste sítio.

João Aldeia 